\title{
Predictive Factors of Early Mortality after Living Donor Liver Transplantation: A Single Center Experience of 780 Cases over 16 Years
}

\author{
Mohamed Abdel Wahab ${ }^{1}$, Ahmad Mohamed Sultan ${ }^{1}$, Amr Yasesn ${ }^{2}$, Omar Fathi ${ }^{1}$, Tarek Salah ${ }^{1}$, \\ Mohamed Elshobari ${ }^{1}$, Mohamed Elsadany ${ }^{3}$, Ehab E Abdel-khalek ${ }^{3}$, Mohamed Elmorshedi ${ }^{2}$, \\ Ahmed Monir ${ }^{1}$, Mohamed Eldesoky ${ }^{1}$, Rami Said ${ }^{1}$, Moataz M Emara², Mostafa Abdelkhalek ${ }^{2}$, \\ Mahmoud Elsedeiq ${ }^{2}$, Karem Abuzeed ${ }^{2}$, Ahmed Shehta ${ }^{{ }^{*}}$
}

\author{
*Corresponding author: \\ Ahmed Shehta, MD \\ Lecturer of surgery \\ Liver Transplantation Unit, \\ Gastrointestinal Surgery Center, \\ College of Medicine, Mansoura \\ University, Egypt \\ Address: Gastrointestinal Surgery \\ Center, Gehan Street, Mansoura, \\ Egypt-Postal code: 35516 \\ Mobile: +2 01003814174 \\ E-mail: ahmedshehta@mans.edu.eg
}

\author{
'Liver Transplantation Unit, Gastrointestinal Surgery Center, Department of Surgery, \\ College of Medicine, Mansoura University, Egypt. \\ ${ }^{2}$ Department of Anesthesia and Intensive Care, Gastrointestinal Surgery Center, \\ College of Medicine, Mansoura University, Egypt. \\ ${ }^{3}$ Department of Hepatology, Gastrointestinal Surgery Center, College of Medicine, \\ Mansoura University, Egypt.
}

\section{ABSTRACT}

Introduction: Living-donor liver transplantation (LDLT) is a complex procedure requiring a special perioperative patients' care. Despite the improvements in the operative techniques and perioperative care, early postoperative mortality remains a disappointing event. The current study is conducted to determine the incidence, causes and potential predictive factors of early postoperative mortality after LDLT.

Methods: We reviewed the data of patients who underwent LDLT during the period between May 2004 till October 2020.

Results: During the study period, 780 cases underwent LDLT. Early Mortality occurred in 109 cases $(14 \%)$. We divided our cases into two groups, Early Mortality group $(n=109)$ and Survivors group $(n=671)$. Higher preoperative INR, creatinine, and MELD score were found in Early Mortality group. More blood loss and perioperative transfusions were found in Early Mortality group. Longer ICU stay with higher incidence of pulmonary and vascular complications were found in Early Mortality group. Preoperative MELD score, blood transfusion, pulmonary complications, and vascular complications were significant predictors of early mortality in multivariate analysis.

Conclusion: Reduction of perioperative transfusions together with early detection and management of vascular and respiratory complications are essential to reduce early mortality after LDLT.

Key words: living-donor liver transplantation, early mortality, MELD score, blood transfusion

\section{INTRODUCTION}


affects millions of individuals worldwide. HCV-infected individuals have a very high risk for mortality when they are compared to the non-infected individuals because of complications of liver decompensation and hepatocellular carcinoma (HCC)(1). Egypt is a densely inhabited county, which has one of the highest prevalence of HCV infection worldwide, with a predominance of genotype 4 (2).

Liver transplantation is widely accepted as the only effective treatment for patients with end stage liver disease (ESLD) and selected hepatic malignancies (3). In Egypt, deceased donor liver transplantation (DDLT) program is still awaited because of legal aspects, making living donor liver transplantation (LDLT) the only hope for patients with ESLD because of chronic HCV infection with or without HCC $(4,5)$.

LDLT is a very complex surgical procedure requiring a special perioperative patients' care. Despite the improvements in the operative techniques and perioperative care, early postoperative mortality remains a disappointing event to the medical staff and patients' families. Several factors had been identified as potential risk factors that affect the outcomes of LDLT, especially during the early postoperative period (6-8). However, the early postoperative mortality after LDLT remains unpredictable.

The current study is conducted to review our center's experience of LDLT over 16 years to determine the incidence and causes of early postoperative mortality and to determine potential predictive factors for early postoperative mortality.

\section{PATIENTS AND METHODS}

\section{Study design}

We reviewed the data of patients who underwent LDLT at Liver Transplantation Unit, Gastrointestinal Surgery Center, Mansoura University, Egypt during the period between May 2004 till October 2020.

Patient data were reviewed from a prospectively maintained database for all patients undergoing LDLT. A written informed consent for the surgical procedure was obtained from each patient. This study was approved by the institutional review board and local ethical committee at Faculty of Medicine, Mansoura University.

\section{Preoperative assessment}

Preoperative evaluation protocol had been described previously $(5,9)$. In summary, preoperative evaluation of potential recipients included 4 phases:

Phase I included detailed laboratory evaluation including tumor markers and virological evaluation, detailed radiological evaluation, and anesthetic consultation. Phase II included detailed cardiopulmonary and neuro-psychiatric evaluation. Phase III included endoscopic evaluation, including upper and lower gastro-intestinal tract endoscopy. Phase IV included routine general consultations to exclude possible hidden septic foci.

\section{Operative techniques}

The operative technique had been described before $(5,9)$. A standard right hemi-liver graft was commonly used for adult LDLT. The liver graft was implanted into the hepatic fossa. Reconstruction of the hepatic venous outflow was done first, followed by portal, arterial, and biliary reconstruction. After ensuring adequate hemostasis, abdominal drains were placed around the graft and near the raw surface.

\section{Postoperative care}

\section{Intensive care unit (ICU) care}

After surgery, all cases were transferred to the ICU for monitoring. Patients underwent detailed laboratory evaluation twice daily during the ICU stay. Oral intake and ambulation were allowed on the third postoperative day. Patients were transferred to the ward on the fifth postoperative day, depending on clinical improvement.

\section{Radiological evaluation}

Our postoperative protocol included Doppler ultrasound (US) examinations once daily during the first week, every other day during the second and third weeks and before hospital discharge, then once weekly during the following 2 months. Further radiological work up was done upon suspicion of any postoperative complications.

\section{Follow up}

After discharge, patients were followed up regularly on outpatient visits. Patients were followed once every week in the first month, then every 2 weeks in the second and third months, then every month till the end of the first year, then every 3 months afterwards or on patient's demand. 
Follow-up visit included detailed history taking, clinical examination, detailed laboratory evaluation including trough level of immunosuppression drugs, and Doppler US evaluation of hepatic vasculature.

\section{Study definitions}

Postoperative morbidities are defined as adverse events occurring during the postoperative course and graded according to Clavien-Dindo grades (10). Early mortality is defined as patient death during the first 90 days after liver transplantation. Overall survival (OS) is calculated from surgery to documented death or the last follow-up visit.

\section{Statistical analysis}

Shapiro-Wilki test was used to assess the normality of the data. Categorical variables were expressed as number and percentage, and continuous variables were expressed as median and range. Comparison between the two groups was done by chi-square or Mann-Whitney test when appropriate. Regression analysis was performed by Cox regression analysis. Significant variables of univariate analysis were included in the subsequent multivariate analysis. Statistical analysis was performed using the SPSS 20 software (IBM, Chicago, IL, USA). A p-value less than 0.05 was considered statistically significant.

\section{RESULTS}

During the period between May 2004 and October 2020, 780 cases underwent LDLT at Liver Transplantation Unit, Gastrointestinal Surgery Center, Mansoura University, Egypt. Early Mortality occurred in 109 cases (14\%). After a median follow up duration of 41 month (4-189), late mortality occurred in 64 cases $(8.2 \%)$, and 607 cases (77.8\%) were alive.We divided our cases into two groups, Early Mortality group $(n=109)$ and Survivors group $(n=671)$.

\section{Baseline characteristics of the recipients}

The baseline characteristics of the study cases are summarized in table 1 . There were no significant differences between the two groups except for preoperative serum international normalized ratio $(p=$ $0.015)$, serum creatinine $(p=0.022)$, and model for end-stage liver disease (MELD) score $(p=0.013)$.

\section{Operative data of the recipients}

The operative data of the study cases are summarized in table 2. A significantly longer warm ischemia time $(p=0.038)$ and anhepatic phase duration ( $p=0.001$ ) were found in Early Mortality group. More operative blood loss $(p=0.001)$ and perioperative transfusion requirements $(p=0.001)$ were found in Early Mortality group.

Table 1 - Baseline characteristics of the study cases (INR, international normalized ratio; MELD, model for end stage liver disease)

\begin{tabular}{|c|c|c|c|}
\hline Variables & $\begin{array}{l}\text { Early Mortality } \\
(n=109)\end{array}$ & $\begin{array}{l}\text { Survivors } \\
(\mathrm{n}=671)\end{array}$ & $P$ value \\
\hline Waiting period (month) & $5(1.8-20)$ & $5(0.9-59)$ & 0.941 \\
\hline Age (years) & $53(5-65)$ & $51(10-67)$ & 0.09 \\
\hline $\begin{array}{l}\text { Sex } \\
\text { Male } \\
\text { Female }\end{array}$ & $\begin{array}{l}91(83.5 \%) \\
18(16.5 \%)\end{array}$ & $\begin{array}{l}575(85.6 \%) \\
96(14.3 \%)\end{array}$ & 0.56 \\
\hline Body mass index $\left(\mathrm{kg} / \mathrm{m}^{2}\right)$ & $28(18-37)$ & $28.7(15-43.5)$ & 0.614 \\
\hline Albumin $(\mathrm{g} / \mathrm{dl})$ & $2.9(1.7-5)$ & $3(1.5-5.5)$ & 0.86 \\
\hline Bilirubin (mg/dl) & $3(0.6-16.5)$ & $2.5(0.3-33.6)$ & 0.093 \\
\hline INR & $1.5(1-4)$ & $1.4(1-4.9)$ & 0.015 \\
\hline Creatinine (mg/dl) & $0.9(0.9-2.2)$ & $0.8(0.5-2.2)$ & 0.022 \\
\hline Child Pugh Score & $9(5-14)$ & $9(5-15)$ & 0.096 \\
\hline MELD Score & $16(6-34)$ & $14(6-48)$ & 0.013 \\
\hline Alpha feto-protein (ng/ml) & $6(1.4-235)$ & $6(1-521)$ & 0.918 \\
\hline $\begin{array}{l}\text { Cause of transplantation } \\
\text { Liver cirrhosis } \\
\text { Hepatocellular carcinoma }\end{array}$ & $\begin{array}{l}79(72.5 \%) \\
30(27.5 \%)\end{array}$ & $\begin{array}{l}437(65.1 \%) \\
234(34.9 \%)\end{array}$ & 0.156 \\
\hline
\end{tabular}


Table 2 - Operative data of the study cases

\begin{tabular}{|c|c|c|c|}
\hline Variables & $\begin{array}{l}\text { Early Mortality } \\
(\mathrm{n}=109)\end{array}$ & $\begin{array}{l}\text { Survivors } \\
(n=671)\end{array}$ & $P$ value \\
\hline Graft weight (gm) & $782(391-1654)$ & $857(436-1545)$ & 0.069 \\
\hline Graft weight to Recipient weight Ratio (GRWR) & $0.95(0.75-2.4)$ & $1.03(0.78-2.58)$ & 0.264 \\
\hline Ascites volume (L) & $2(0-21)$ & $0.3(0-26)$ & 0.059 \\
\hline Cold ischemia time (minutes) & $34(12-150)$ & $30(10-175)$ & 0.31 \\
\hline Warm ischemia time (minutes) & $42(23-130)$ & $37(17-137)$ & 0.038 \\
\hline Anhepatic phase duration (minutes) & $78(40-175)$ & $66(25-173)$ & 0.001 \\
\hline Operation time (minutes) & $660(420-1080)$ & $600(345-900)$ & 0.061 \\
\hline Blood loss (ml) & $11750(900-7000)$ & $6750(300-39000)$ & 0.001 \\
\hline Blood transfusion & $78(71.9 \%)$ & $549(81.8 \%)$ & 0.001 \\
\hline $\begin{array}{l}\text { Hepatic veins number } \\
1 \\
2 \\
3 \\
4 \\
5\end{array}$ & $\begin{array}{l}50(45.9 \%) \\
35(32.1 \%) \\
22(20.2 \%) \\
1(0.9 \%) \\
1(0.9 \%)\end{array}$ & $\begin{array}{l}383(57.1 \%) \\
202(30.1 \%) \\
68(10.1 \%) \\
17(2.5 \%) \\
1(0.1 \%)\end{array}$ & 0.008 \\
\hline $\begin{array}{l}\text { Portal vein number } \\
1 \\
2\end{array}$ & $\begin{array}{l}102(93.6 \%) \\
7(6.4 \%)\end{array}$ & $\begin{array}{l}637(94.9 \%) \\
34(5.1 \%)\end{array}$ & 0.494 \\
\hline Portal thrombectomy & $6(5.5 \%)$ & $15(2.2 \%)$ & 0.063 \\
\hline $\begin{array}{l}\text { Hepatic artery number } \\
1 \\
2\end{array}$ & $\begin{array}{l}105(96.3 \%) \\
4(3.7 \%)\end{array}$ & $\begin{array}{l}663(98.8 \%) \\
8(1.2 \%)\end{array}$ & 0.073 \\
\hline $\begin{array}{l}\text { Bile duct number } \\
1 \\
2 \\
3\end{array}$ & $\begin{array}{l}62(56.9 \%) \\
44(40.4 \%) \\
3(2.8 \%)\end{array}$ & $\begin{array}{l}396(59 \%) \\
258(38.5 \%) \\
17(2.5 \%)\end{array}$ & 0.915 \\
\hline
\end{tabular}

\section{Post-operative data of the recipients}

Early mortality occurred in 109 cases (14\%). Causes of early mortality are summarized in table 3 . The most common causes of early postoperative mortality were respiratory problems ( 24 cases $-22 \%$ ), vascular problems (20 cases $-18.3 \%$ ), and sepsis (14 cases $-12.8 \%)$.

The postoperative data of the study cases are summarized in table 4. Longer intensive care unit stay was noted in Early Mortality group $(p=0.001)$. There were no significant differences between the two groups regarding wound-related problems $(p=0.519)$, overall biliary complications $(p=0.193)$, and abdominal collections $(p=0.72)$. Higher incidence of pulmonary complications $(p=0.001)$ and vascular complications $(p=0.001)$ were found in Early Mortality group.

\section{Predictors of early postoperative mortality}

Predictive factors for early postoperative mortality are summarized in table 5. On univariate analysis, serum bilirubin, serum creatinine, Child-Pugh score, MELD score, graft weight, warm ischemia time,
Table 3 - Causes of early postoperative mortality

\begin{tabular}{ll}
\hline Causes & Number (109) \\
\hline Chest troubles & $24(22 \%)$ \\
- Acute respiratory distress syndrome & $5(4.6 \%)$ \\
- Pneumonia & $15(13.8 \%)$ \\
- Viral pneumonia & $2(1.8 \%)$ \\
- Pulmonary edema & $1(0.9 \%)$ \\
Vascular troubles & $1(0.9 \%)$ \\
- Anterior sector congestion & $20(18.3 \%)$ \\
- Hepatic venous outflow obstruction & $1(0.9 \%)$ \\
- Portal vein thrombosis & $7(6.4 \%)$ \\
- Hepatic artery thrombosis & $5(4.6 \%)$ \\
Sepsis & $7(6.4 \%)$ \\
(bleeding and transfusion related lung injury) & $14(12.8 \%)$ \\
\hline Neurological troubles & $13(11.9 \%)$ \\
- Cerebral hemorrhage & \\
- Cerebellar hemorrhage & $12(11 \%)$ \\
- Multiple brain infarctions & $5(4.6 \% \%)$ \\
- Central pontine myelolysis & $1(0.9 \%)$ \\
- Subarachnoid hemorrhage & $2(1.8 \%)$ \\
- Tacrolimus (FK) induced neurotoxicity & $1(0.9 \%)$ \\
- Withdrawal syndrome & $1(0.9 \%)$ \\
Primary non function of the graft & $1(0.9 \%)$ \\
\hline Small for size syndrome & $1(0.9 \%)$ \\
\hline Cardiac troubles (acute myocardial infarction) & $10(9.2 \%)$ \\
\hline Senal troubles (acute renal failure) & $6(5.5 \%)$ \\
\hline
\end{tabular}


Table 4 - Postoperativedataof the study cases

(ICU, intensive care unit; HAT, hepatic artery thrombosis; PVT, portal vein thrombosis; PVS, portal vein stenosis)

\begin{tabular}{|c|c|c|c|}
\hline Variables & $\begin{array}{l}\text { Early Mortality } \\
(n=109)\end{array}$ & $\begin{array}{l}\text { Survivors } \\
(\mathrm{n}=671)\end{array}$ & $P$ value \\
\hline ICU stay (days) & $7(2-45)$ & $6(4-60)$ & 0.001 \\
\hline Hospital stay (days) & $16(2-90)$ & $21(7-135)$ & 0.001 \\
\hline $\begin{array}{l}\text { Wound problems } \\
\text { Infection } \\
\text { Hematoma }\end{array}$ & $\begin{array}{l}0 \\
0\end{array}$ & $\begin{array}{l}5(0.7 \%) \\
3(0.4 \%)\end{array}$ & 0.519 \\
\hline Internal hemorrhage & $13(11.9 \%)$ & $19(2.8 \%)$ & 0.01 \\
\hline $\begin{array}{l}\text { Biliary complications } \\
\text { Overall } \\
\text { Leak } \\
\text { Biloma } \\
\text { Stricture }\end{array}$ & $\begin{array}{l}16(14.7 \%) \\
9(8.3 \%) \\
10(9.2 \%) \\
0\end{array}$ & $\begin{array}{l}137(20.4 \%) \\
56(8.3 \%) \\
59(8.8 \%) \\
85(12.7 \%)\end{array}$ & $\begin{array}{c}0.193 \\
1 \\
0.856 \\
0.001\end{array}$ \\
\hline Abdominal collections & $6(5.5 \%)$ & $26(3.9 \%)$ & 0.72 \\
\hline $\begin{array}{l}\text { Vascular complications } \\
\text { Overall } \\
\text { HAT } \\
\text { PVT } \\
\text { PVS } \\
\text { Venous congestion }\end{array}$ & $\begin{array}{l}26(23.9 \%) \\
7(6.4 \%) \\
5(4.6 \%) \\
0 \\
18(16.5 \%)\end{array}$ & $\begin{array}{l}51(7.6 \%) \\
7(1 \%) \\
6(0.9 \%) \\
6(0.9 \%) \\
37(5.5 \%)\end{array}$ & $\begin{array}{l}0.001 \\
0.017 \\
0.005 \\
0.001 \\
0.001\end{array}$ \\
\hline Significant pulmonary complications & $24(22 \%)$ & $18(2.7 \%)$ & 0.001 \\
\hline
\end{tabular}

Table 5 - Predictors of early postoperative mortality

(HR, hazard ratio; $\mathrm{Cl}$, confidence interval; INR, international normalized ratio; MELD, model for end-stage liver disease; PV, portal vein; HV, hepatic vein; HA, hepatic artery)

\begin{tabular}{|c|c|c|c|c|}
\hline \multirow[t]{2}{*}{ Variables } & \multicolumn{2}{|c|}{ Univariate Analysis } & \multicolumn{2}{|c|}{ Multivariate Analysis } \\
\hline & $\mathrm{HR}(95 \% \mathrm{Cl})$ & $P$ value & HR $(95 \% \mathrm{Cl})$ & $P$ value \\
\hline$\overline{\mathrm{Age}}$ & $1.012(0.991-1.034)$ & 0.256 & & \\
\hline Sex & $1.179(0.711-1.954)$ & 0.524 & & \\
\hline Body mass index & $0.986(0.944-1.029)$ & 0.518 & & \\
\hline Albumin & $0.843(0.608-1.167)$ & 0.303 & & \\
\hline Bilirubin & $1.061(1.017-1.017)$ & 0.006 & $1(0.85-1.176)$ & 0.996 \\
\hline INR & $1.03(0.907-1.168)$ & 0.65 & & \\
\hline Creatinine) & $1.723(1.49-3.13)$ & 0.03 & $2.442(0.486-12.275)$ & 0.279 \\
\hline Child Pugh Score & $1.156(1.02-1.311)$ & 0.023 & $1.113(0.759-1.633)$ & 0.582 \\
\hline MELD Score & $1.049(1.017-1.083)$ & 0.003 & $1.056(1.03-1,237)$ & 0.01 \\
\hline Pathologic diagnosis & $0.74(0.486-1.126)$ & 0.16 & & \\
\hline Ascites volume & $1.024(0.989-1.06)$ & 0.188 & & \\
\hline Graft weight & $0.24(0.069-0.835)$ & 0.025 & $1.156(0.953-1.403)$ & 0.141 \\
\hline GRWR & $0.976(0.827-1.152)$ & 0.774 & & \\
\hline Cold ischemia time & $1.006(0.998-1.013)$ & 0.118 & & \\
\hline Warm ischemia time & $1.011(1.002-1.02)$ & 0.015 & $0.954(0.89-1.022)$ & 0.177 \\
\hline Anhepatic phase duration & $1.01(1.006-1.014)$ & 0.001 & $1.015(0.998-1.032)$ & 0.085 \\
\hline Operation time & $1.005(1.003-1.006)$ & 0.001 & $1(0.995-1.004)$ & 0.936 \\
\hline Blood loss & $1(1-1)$ & 0.001 & $1(1-1)$ & 0.887 \\
\hline Blood transfusion & $1.124(1.092-1.156)$ & 0.001 & $1.134(1.012-1.271)$ & 0.03 \\
\hline PV thrombectomy & $3.095(0.998-9.597)$ & 0.05 & & \\
\hline HV number & $1.286(1.042-1.586)$ & 0.019 & $1.303(0.644-2.635)$ & 0.461 \\
\hline $\mathrm{PV}$ number & $1.283(0.597-2.76)$ & 0.523 & & \\
\hline HA number & $2.829(1.041-7.689)$ & 0.041 & $1.129(0.171-7.556)$ & 0.9 \\
\hline Bile duct number & $1.064(0.758-1.495)$ & 0.719 & & \\
\hline Wound problems & $1.2(0.423-11.939)$ & 0.656 & & \\
\hline Significant pulmonary complications & $6.327(4.012-9.98)$ & 0.001 & $0.017(0.001-0.377)$ & 0.01 \\
\hline Internal hemorrhage & $2.625(1.327-5.193)$ & 0.006 & $3.254(0.749-14.18)$ & 0.115 \\
\hline Biliary complications & $0.676(0.397-1.149)$ & 0.147 & & \\
\hline Vascular complications & $2.06(1.969-4.755)$ & 0.001 & $3.534(1.061-11.769)$ & 0.04 \\
\hline Abdominal collections & $1.149(0.75-1.759)$ & 0.523 & & \\
\hline
\end{tabular}


anhepatic phase duration, operation time, blood loss, blood transfusion, hepatic veins anastomosis number, hepatic artery anastomosis number, postoperative pulmonary complications, postoperative internal hemorrhage, and postoperative vascular complications were significantly associated with early post-operative mortality. On multivariate analysis, pre-operative MELD score, blood transfusion, postoperative pulmonary complications, and postoperative vascular complications were significant predictors of early postoperative mortality.

\section{DISCUSSION}

Liver transplantation has been established as the only effective treatment for patients with ESLDdue to various causes as viral hepatitis and metabolic disorders, and certain hepatic malignancies (3). LDLT has been rapidly developing all over the world and is currently established as a safe and acceptable alternative to DDLT $(3,11)$. In Egypt, DDLT program is still awaited due to several legal limitations, making LDLT the only hope for patients with ESLD with or without $\operatorname{HCC}(4,5)$. In our unit, LDLT program was started in $\mathbf{2 0 0 4}$ for the management of patients from a highly populated Delta region in the north side of Egypt (2). The liver transplantation team in our unit is a totally independent team. All team members including surgeons, hepatologists, anesthesiologists, intensivists, radiologists and pathologists are exclusively Mansoura University staff.

LDLT is a very complex surgical procedure requiring a special perioperative patients' care anda complex infrastructure availability. Despite the improvements in the operative techniques and perioperative patients' care, early postoperative mortality remains a disappointing event. Previous studies had reported varying incidence of early mortality after liver transplantation (table 6). Li et al. reported early mortality incidence of $11.9 \%$ after LDLT with 3-month overall survival of $88.1 \%$ (12). Vrochides et al. reported earlymortality incidence of $12.4 \%$ after liver transplantation (7). In a study from Egypt, Elkholy et al. reported early mortality among 29 patients (23\%) who underwent LDLT (13). In another study, El Amir et al. reported 3-month mortality rate of $24.4 \%$ and 1 -year mortality of $31.4 \%$ among patients who underwent LDLT (14). In our study, early postoperative mortality occurred in 109 cases (14\%) who underwent LDLT. The relatively high early mortality rate could be attributed to several factors. Firstly, and most essential, is the lack of a back-up of DDLT program which is still awaited in our locality (4). In our opinion,active legalization of DDLT program in our locality is essentially needed to overcome the shortage of available liver grafts in Egypt and to back-up the ongoing LDLT programs. In our study, more than $20 \%$ of early mortality cases, owing to primary non-function of the graft or severe vascular complications, could be saved with the availability of DDLT program. Secondly, higher preoperative MELD score among patients undergoing LDLT as a major proportion of our patients are referred at a late disease stage. Finally, acceptance of donors with multiple anatomical variations due to the problem of donor shortage as we allow only livingrelated transplantation (4).

Previous studies had identified different causes of early postoperative mortality after liver transplantation. Elkholy et al. found that sepsis was the commonest cause of early mortality after LDLT (13). Nafea et al. found that sepsis followed by acute rejection were the commonest causes of early mortality (15). Li et al. reported that multi-organ failure was the commonest cause of early mortality (12). El Amir et al. found that infectious complications, pneumonia and sepsis, were the commonest cause of early mortality after LDLT (14). In our study, we found that respiratory complicationsfollowed by vascular complications and sepsis were the commonest causes of early mortality after LDLT.

Identification of different predictive factors for early

Table 6 - Studies reporting early mortality (90 days mortality) after living-donor liver transplantation

\begin{tabular}{lll}
\hline Study & Total number of cases & Early postoperative mortality \\
\hline Li et al $(12)$ & 218 patients & 26 patients $(11.9 \%)$ \\
\hline Elkholy et al $(13)$ & 126 patients & 29 patients $(23 \%)$ \\
\hdashline ElAmir et al $(14)$ & 86 patients & 21 patients $(24.42 \%)$ \\
\hdashline Nafea et al $(15)$ & 122 patients & 28 patients $(22.8 \%)$ \\
\hline Freise et al $(32)$ & 384 patients & 34 patients $(8.5 \%)$ \\
\hline Akamatsu et al $(33)$ & 445 patients & 23 patients $(5 \%)$ \\
Li et al $(34)$ & 235 patients & 31 patients $(13.2 \%)$ \\
\hdashline Alves et al $(35)$ & 78 patients & 16 patients $(20.5 \%)$ \\
\hline
\end{tabular}


postoperative mortality after liver transplantation is essential to optimize the selection of appropriate candidates, control of correctable causes, and achieve favorable outcomes (16).

Several predictive factors for early mortality had been identified. These include preoperative, operative, and postoperative factors. Preoperative factors include higher MELD score, small liver graft volume, poor quality liver grafts, and older donor age. Operative factors include larger amounts of blood loss and transfusion requirements, longer anhepatic phase duration, longer cold and warm ischemia times, and technical troubles. Postoperative factors include postoperative transfusion requirements, longer ICU and hospital stay and abnormal postoperative laboratory values $(12,16)$. In the current study, we evaluated our experience of 780 consecutive cases of LDLTin a single center to determine different predictive factors for early postoperative mortality. To the best of our knowledge this is the largest series of LDLT from a single center in our locality.We found that preoperative MELD score, blood transfusion requirements, post-operative pulmonary complications, and postoperative vascular complications were significant predictors of early postoperative mortality on multivariate regression analysis.

MELD Score has been validated as a predictor of survival in patients with cirrhosis, alcoholic hepatitis, and in patients with acute hepatitis. Afterwards, it has been widely used to allocate patients under waiting list for liver transplantation and predict the earlymortality (17). Kidney dysfunction is commonly seen in almost 10 $20 \%$ of liver transplantation candidates. Previous studies had shown that kidney dysfunction is associated with prolonged hospitalstay, higher incidence of infectious complications, and poor survival outcomes (18-20). In our study, preoperative MELD score was a significant predictor of early and mortality and was significantly higher in the early mortality patients. Similar finding has been addressed by previous studies. Vrochides et al addressed that preoperative MELD score together with preoperative serum bilirubin, INR, and creatinine were significant predictors of early mortality (7). Elkholy et al. addressed that preoperative MELD score higher than 20 was a significant predictor of early mortality (13). On the other hand, El Amir et al. found that preoperative MELD score failed to predict both early postoperative and 1-year mortality after LDLT (14). Similarly, Chok et al addressed that higher MELD score group had com-parable early mortality in comparison to lower MELD score group (21).

Perioperative blood transfusion had been identified as a poor predictor of recipient outcomes after liver transplantation $(22,23)$. Several studies had addressed that excess perioperative transfusions were associated with prolonged hospital stay, higher incidence of infectious complications, and poor survival outcomes after liver transplantation $(24,25)$. In the current study, we found that perioperative transfusion was a significant predictor for early postoperative mortality. Similar finding had been addressed by Li et al. who found that intraoperative allogeneic red blood cell transfusion was a significant predictor of early mortality (12). Elkholy et al. addressed that intraoperative transfusion of more than 8 units of packed red blood cells was a significant predictor of early mortality (13). Ye-Ben et al. reported that the amount of operative blood loss and transfusion requirements had a significant association with early mortality (26).

Postoperative morbidities following major abdominal surgeries are associated with reduced survival outcomes (27). LDLT is a very complex surgery that is associated with high risk for the development of several postoperative complications which can cause graft loss and early postoperative mortality $(28,29)$. Recipients are at a very high risk for the development of a wide variety of postoperative complications including biliary, vascular, infectious, renal, neurological, and cardiac complications (29). In our study, we found that the development of postoperative pulmonary complications, and postoperative vascular complications were significant predictors of early postoperative mortality. Duffy et al addressed that the development of vascular complications, especially hepatic artery thrombosis and portal vein thrombosis, were significantly associated with reducedliver graft and recipient survival. They addressed that retransplantation provides the most superior short-term for patients with hepatic artery thrombosis (30). Such backup with cadaveric programs is still lacking in our locality. On the other hand, Bozbas et al. showed that pulmonary complications after liver transplantation, especially pleural effusion and pneumonia, were significantly associated with early mortality. Early and late survival rates were significantly lower in patients in whom a microorganism was isolated on deep tracheal aspirate culture (31). Other studies did not find any significant association between postoperative morbidities and early mortality after liver transplantation $(12,13,15)$. Avoidance, early detection, and proper management of early postoperative vascular and pulmonary complications are essential to reduce early postoperative mortality.

Our study had some limitations. Firstly, it is a single center retrospective study. Secondly, we did not evaluate any of the postoperative laboratory 
parameters in the regression model. Further studies on a large number of patients from multiple centers are needed to support our findings.

\section{CONCLUSION}

In conclusion,early postoperative mortality after LDLTis a disappointing event to the medical staff and patients' families. We found that preoperative MELD score, blood transfusion, postoperative pulmonary complications, and postoperative vascular complications were significant predictors of early postoperative mortality. Reduction of perioperative transfusions together with early detection and management of vascular and respiratory complications are essential to reduce early postoperative mortality. A DDLT program is essentially needed to back up ongoing LDLT programs in our locality.

\section{Acknowledgements: none.}

\section{Financial disclosures}

No external funding resources.

\section{Conflicts of interest}

All authors declare no conflicts of interest.

\section{Ethical approval}

The study was approved by the institutional review board and local ethical committee at Faculty of Medicine, Mansoura University.

\section{REFERENCES}

1. Daw MA, El-Bouzedi AA, Ahmed MO, Dau AA, Agnan MM, Drah AM. Geographic integration of hepatitis $C$ virus: a global threat. World J Virol. 2016:5(4):170-182

2. Galal HE, Azza HE. Liver transplantation in Egypt from West to East. Transplant Research and Risk Management 2010;2:41-46.

3. Olthoff KM, Merion RM, Ghobrial RM, Abecassis MM, Fair JH, Fisher RA, et al. Outcomes of 385 adult-to-adult living donor liver transplant recipients: a report from the A2ALL consortium. Ann Surg. 2005;242(3):314-23, discussion 323-5.

4. Wahab MA, Hamed H, Salah T, Elsarraf W, Elshobary M, Sultan AM et al. Problem of living liver donation in the absence of deceased liver transplantation program: Mansoura experience. World $J$ Gastroenterol. 2014;20(37):13607-14.

5. Wahab MA, Shehta A, Elshoubary M, Yassen AM, Elmorshedi M, Salah T, et al. Living-donor liver transplantation in hepatitis $C$ virus era: a report of 500 consecutive cases in a single center. Transplant Proc. 2018;50(5):1396-1406.

6. Santori G, Andorno E, Antonucci A, Morelli N, Bottino G, Mondello $\mathrm{R}$, et al. Potential predictive value of the MELD score for short-term mortality after liver transplantation. Transplant Proc. 2004;
36(3):533-4.

7. Vrochides D, Hassanain M, Barkun J, Tchervenkov J, Paraskevas S, Chaudhury $\mathrm{P}$, et al. Association of preoperative parameters with postoperative mortality and long-term survival after liver transplantation. Can J Surg. 2011;54(2):101-6.

8. Dawwas MF, Lewsey JD, Watson CJ, Gimson AE; UK, Ireland Liver Transplant Audit. The impact of serum potassium concentration on mortality after liver transplantation: a cohort multicenter study. Transplantation 2009;88(3):402-410.

9. Wahab MA, Shehta A, Elshoubary M, Salah T, Fathy 0, Sultan A, et al. Outcomes of Living Donor Liver Transplantation for Patients with Preoperative Portal Vein Problems. J Gastrointest Surg 2018; 22(12):2055-63.

10. Dindo D, Demartines N, Clavien PA. Classification of surgical complications: a new proposal with evaluation in a cohort of 6336 patients and results of a survey. Ann Surg 2004;240(2):205.

11. PomfretEA, Fryer JP, Sima CS, Lake JR, Merion RM. Liver and intestine transplantation in the United States, 1996-2005. Am J Transplant. 2007;7(5 Pt 2):1376-89.

12. Li C, Wen TF, Yan LN, Li B, Yang JY, Wang WT, et al. Factors associated with early mortality after living-donor liver transplant. Experimental and clinical transplantation 2014;13(1):62-7.

13. Elkholy S, Mogawer S, Hosny A, El-Shazli M, Al-Jarhi UM, Abdel-Hamed $S$, et al. Predictors of mortality in living donor liver transplantation. Transplant Proc 2017;49(6):1376-1382.

14. El Amir M, Eldeen HG, Mogawer S, Esmat G, El-Shazly M, El-Garem $\mathrm{N}$, et al. Different score systems to predict mortality in living donor liver transplantation: which is the winner? The experience of an Egyptian center for living donor liver transplantation. Transplant Proc 2015;47(10):2897-901

15. Nafea MA, Alsebaey A, Abd El Aal Sultan A, Goda MH, Salman A, Rashed HS, et al. Predictors of early recipient mortality after living donor liver transplantation in a tertiary care center in Egypt. Annals of Saudi Medicine 2019;39(5):337-44.

16. Olivari D, Mainardi V, Rando K, Rey G, Menendez J, Prieto J, et al. Risk factors of mortality after liver transplantation in Uruguay. Transplant Proc 2018;50(2):499-502.

17. Kamath PS, Wiesner RH, Malinchoc M, Kremers W, Therneau TM, Kosberg CL, et al. A model to predict survival in patients with endstage liver disease. Hepatology 2001;33(2):464-70.

18. Park I, Moon E, Hwang JA, Yu S, Kim BW, Wang HJ, et al. Does hepatorenal syndrome affect the result of liver transplantation? Clinical observations. Transplant Proc 2010;42(7):2563-6

19. Kundakci A, Pirat A, Komurcu O, Torgay A, Karakayalı H, Arslan G, et al. Rifle criteria for acute kidney dysfunction following liver transplantation: incidence and risk factors. Transplant Proc. 2010; 42(10):4171-4.

20. Northup PG, Argo CK, Bakhru MR, Schmitt TM, Berg CL, Rosner $\mathrm{MH}$. Pretransplant predictors of recovery of renal function after liver transplantation. Liver Transpl. 2010;16(4):440-446.

21. Chok KSh, Chan SC, Fung JY, Cheung TT, Chan AC, Fan ST, et al. Survival outcomes of right-lobe living donor liver transplantation for patients with high Model for End-stage Liver Disease scores Hepatobiliary Pancreat Dis Int. 2013;12(3):256-62.

22. Dunn LK, Thiele RH, Ma JZ, Sawyer RG, Nemergut EC. Duration of red blood cell storage and outcomes following orthotopic liver transplantation. Liver Transpl 2012;18(4):475-481.

23. Wiederkehr JC, Igreja MR, Nogara MS, Gonçalves NL, Wiederkehr $\mathrm{BA}$, Nascimento VB, et al. Analysis of survival after primary liver transplantation: multivariate analysis of 155 cases in a single center. Transplant Proc 2010;42(2):511-2.

24. Ramos E, Dalmau A, Sabate A, Lama C, Llado L, Figueras J, et al. Intraoperative red blood cell transfusion in liver transplantation: influence on patient outcome, prediction of requirements, and measures to reduce them. Liver Transpl 2003;9(12):1320-7.

25. Benson AB, Burton JR Jr, Austin GL, Biggins SW, Zimmerman MA, Kam I, et al. Differential effects of plasma and red blood cell transfusions on acute lung injury and infection risk following liver transplantation. Liver Transpl. 2011;17(2):149-58.

26. Qian YB, Cheng GH, Huang JF. Multivariate regression analysis on early mortality after orthotopic liver transplantation. World $\mathrm{J}$ 
Gastroenterol 2002;8(1):128-30

27. Khuri SF, Henderson WG, DePalma RG, Mosca C, Healey NA, Kumbhani DJ. Determinants of long-term survival after major surgery and the adverse effect of postoperative complications. Ann Surg 2005;242:326-341.

28. Gad EH, Alsebaey A, Lotfy M, Eltabbakh M, Sherif AA. Complications and mortality after adult to adult living donor liver transplantation: a retrospective cohort study. Ann Med Surg (Lond) 2015;4:162-171.

29. Parikh A, Washburn KW, Matsuoka L, Pandit U, Kim JE, Almeda J, et al. A multicenter study of 30 days complications after deceased donor liver transplantation in the model for end-stage liver disease score era. Liver Transpl. 2015;21(9):1160-8.

30. Duffy JP, Hong JC, Farmer DG, Ghobrial RM, Yersiz H, Hiatt JR, et al. Vascular complications of orthotopic liver transplantation: experience in more than 4,200 patients. J Am Coll Surg 2009; 208(5):896-903.

31. Bozbas SS, Eyuboglu FO, Ergur FO, Arslan NG, Sevmis S, Karakayali
$\mathrm{H}$, et al. Pulmonary complications and mortality after liver transplant. Exp Clin Transplant. 2008;6(4):264-70.

32. Freise CE, Gillespie BW, Koffron AJ, Lok ASF, Pruett TL, Emond JC, et al. Recipient morbidity after living and deceased donor liver transplantation: findings from the A2ALL retrospective cohortstudy. Am J Transplant. 2008;8(12):2569-79.

33. Akamatsu N, Sugawara $\mathrm{Y}$, Kanako J, Junichi Arita, Sakamoto $\mathrm{Y}$ Hasegawa K, et al. Low platelet counts and prolonged prothrombin time early after operation predict the 90 days morbidity and mortality in living-donor liver transplantation. Ann Surg 2017; 265(1):166-72.

34. Li L, Wang H, Yang J, Jiang L, Yang J, Wang W, et al. Immediate postoperative low platelet counts after living donor liver transplantation predict early allograft dysfunction. Medicine 2015;94(34): e1373.

35. Alves RC, Fonseca EA, Mattos CA, Abdalla S, Gonçalves JE, Waisberg J. Predictive factors of early graft loss in living donor liver transplantation. Arquivos de gastroenterologia 2012;49(2):157-61. 